\title{
Rare but deadly manifestation of systemic lupus erythematosus
}

\author{
Sebastian Alejandro Mikulic 다, ${ }^{1}$ Michael Chahin 다, ${ }^{1}$ Sukhraj Singh, ${ }^{2}$ Myint Thway ${ }^{2}$
}

${ }^{1}$ Internal Medicine, University of Florida College of Medicine, Jacksonville, Florida, USA ${ }^{2}$ Department of Medicine Division of Rheumatology, UF Health Jacksonville, Jacksonville, Florida, USA

\section{Correspondence to}

Dr Sebastian Alejandro Mikulic; sebastian.mikulic@jax.ufl.edu

Accepted 18 October 2020

Check for updates

(c) BMJ Publishing Group Limited 2020. No commercial re-use. See rights and permissions. Published by BMJ.

To cite: Mikulic SA, Chahin $M$, Singh $S$, et al. BMJ Case Rep 2020:13:e239646. doi:10.1136/bcr-2020-

239646

\section{DESCRIPTION}

A 26-year-old African-American woman with systemic lupus erythematosus (SLE) and endstage renal disease due to lupus nephritis was sent to the hospital from the dialysis centre following oxygen saturation of $73 \%$ and fever of $101^{\circ} \mathrm{F}$. The patient reported worsening dyspnoea and fatigue for 3 days, which led her to miss her routine dialysis session the day before hospitalisation. The patient has a complex history of SLE manifesting as diffuse cutaneous manifestations, lupus nephritis classes II and V, and autoimmune haemolytic anaemia. She was being treated with prednisone and hydroxychloroquine, but mycophenolate mofetil was discontinued 4 weeks prior due to methicillin-susceptible Staphylococcus aureus bacteraemia.

On examination, she was in moderate respiratory distress requiring supplemental oxygen. The patient's haemoglobin was noted to be $72 \mathrm{~g} / \mathrm{L}$ (baseline $80 \mathrm{~g} / \mathrm{L}$ ) and platelet count 89 thou/cumm (baseline around 160 thou/cumm). Lupus activity markers showed low complement (C3) and elevated double-stranded DNA. Chest X-ray revealed multifocal patchy airspace opacities in bilateral lung fields (figure 1). Her hypoxia had minimal improvement with haemodialysis. Our suspicion for pneumocystis pneumonia was high, given her evolving clinical picture, elevated lactate dehydrogenase and increased arterial-alveolar gradient. We proceeded with bronchoscopy and bronchoalveolar lavage (BAL) revealed serial aliquots of serosanguinous saline indicative of diffuse alveolar haemorrhage $(\mathrm{DAH})$. The patient was immediately started on pulse doses of intravenous methylprednisolone

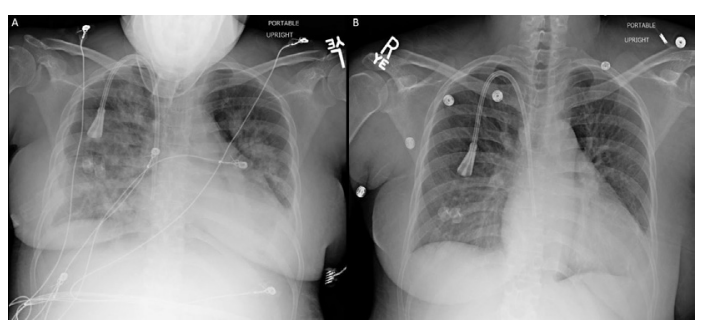

Figure 1 (A) Portable AP chest X-ray showing multifocal patchy airspace opacities through bilateral lung fields, a right lower lung opacity and a right tunnelled catheter. This film was taken after the patient underwent urgent haemodialysis on presentation. (B) Portable AP chest $\mathrm{X}$-ray showing marked improvement in the bilateral patchy opacities with only mild interstitial prominence remaining. This film was taken after receiving methylprednisolone and rituximab. AP, anteroposterior.
$500 \mathrm{mg}$ daily followed by rituximab $375 \mathrm{mg} / \mathrm{m}^{2}$ induction therapy. Cyclophosphamide was not chosen given her recent infection, haemodialysis status, and young age. Her respiratory status improved dramatically, and follow-up chest X-ray revealed improvement in the diffuse patchy airspace opacities.

DAH is an uncommon but life-threatening complication of SLE. It is reported in the literature to occur in $1.0 \%-5.4 \%$ of cases with mortality ranging anywhere from $50 \%$ to $80 \% .{ }^{12}$ The hallmarks of the disease include cough, dyspnoea and haemoptysis, with diffuse lung infiltrates on chest imaging and increasing red blood cells on serial aliquots on BAL. The most commonly associated organ involved in patients with SLE complicated by DAH is nephritis. ${ }^{3}$ In an effort to identify early predictors of DAH development, multivariate analyses found a history of thrombocytopenia and low C3 in one study ${ }^{1}$ and coexisting neuropsychiatric lupus and high Systemic Lupus Erythematosus Disease Activity Index in another study ${ }^{4}$ as strong predictors for developing DAH. High doses of intravenous glucocorticoids is the cornerstone of therapy, along with additional immunosuppressive agents to sustain remission. ${ }^{3}$ Traditionally, cyclophosphamide has been the agent of choice. ${ }^{5}$ During the acute phase of DAH, immediate hemostasis can be achieved with bronchoscopic administration of intrapulmonary recombinant factor VIIa. ${ }^{6}$ Also in cases of refractory hypoxaemia, supportive care with extracorporeal membrane oxygenation has been described. ${ }^{7}$ Recent advances in our understanding of pathogenic mechanisms driving the development of DAH highlight the pivotal role played by B lymphocytes and humoral immunity. ${ }^{8}$ Thus, rituximab (anti-CD20 monoclonal antibody) has been applied successfully in multiple case reports $^{9}$ and in our case as well. This case illustrates a textbook example of how DAH can present, the classic risk factors that serve to increase suspicion and use of emerging immunosuppressive options.

\section{Patient's perspective}

I was aware of my systemic lupus erythematosus diagnosis for multiple years; however, I was surprised to learn how deadly the disease could be once it started to affect my lungs. This has been a very frightening experience that has taught me a lot about my condition. I am very fortunate to have recovered, and I feel extremely relieved to have the opportunity to go back home to my family. 


\section{Learning points}

Diffuse alveolar haemorrhage (DAH) is a life-threatening complication of systemic lupus erythematosus that classically presents with shortness of breath, hemoptysis and bilateral alveolar infiltrates.

- Early bronchoscopy is indicated in patients who are suspected of having DAH as it is used to aid in the diagnosis and rule out infection. A rising red blood cell count in sequential bronchoalveolar lavage aliquots from the same location is considered diagnostic of DAH.

- Corticosteroids and immunosuppressive agents remain the gold standard for the treatment of DAH.

Contributors Each author played a significant role in contributing to this article $M C$ and SAM played a significant role in reviewing the literature and writing the case report. SS played a significant role in planning and editing, along with acquiring the associated images. MT played a significant role in planning, editing and supervising the case. All authors approved the final draft.

Funding The authors have not declared a specific grant for this research from any funding agency in the public, commercial or not-for-profit sectors.

Competing interests None declared.

Patient consent for publication Obtained.

Provenance and peer review Not commissioned; externally peer reviewed.

\section{ORCID iDs}

Sebastian Alejandro Mikulic http://orcid.org/0000-0003-4518-2584

Michael Chahin http://orcid.org/0000-0001-9371-0252

\section{REFERENCES}

1 Mahmoud GA, Gheith RE, Kamel MM, et al. Alveolar hemorrhage in systemic lupus erythematosus: an overview. The Egyptian Rheumatologist 2011;33:1-11.

2 Zamora MR, Warner ML, Tuder R, et al. Diffuse alveolar hemorrhage and systemic lupus erythematosus: clinical presentation, histology, survival, and outcome. Medicine 1997;76:192-202.

3 Kazzaz NM, Coit P, Lewis EE, et al. Systemic lupus erythematosus complicated by diffuse alveolar haemorrhage: risk factors, therapy and survival. Lupus Sci Med 2015;2:e000117.

4 Kwok S-K, Moon S-J, Ju JH, et al. Diffuse alveolar hemorrhage in systemic lupus erythematosus: risk factors and clinical outcome: results from affiliated hospitals of Catholic University of Korea. Lupus 2011;20:102-7.

5 Ednalino C, Yip J, Carsons SE. Systematic review of diffuse alveolar hemorrhage in systemic lupus erythematosus: focus on outcome and therapy. J Clin Rheumatol 2015:21:305-10.

6 Heslet L, Nielsen JD, Levi M, et al. Successful pulmonary administration of activated recombinant factor VII in diffuse alveolar hemorrhage. Crit Care 2006;10:R177.

7 Patel JJ, Lipchik RJ. Systemic lupus-induced diffuse alveolar hemorrhage treated with extracorporeal membrane oxygenation: a case report and review of the literature. J Intensive Care Med 2014;29:104-9.

8 Anderton SM, Fillatreau S. Activated B cells in autoimmune diseases: the case for a regulatory role. Nat Clin Pract Rheumatol 2008;4:657-66.

9 Na JO, Chang SH, Seo K-H, et al. Successful early rituximab treatment in a case of systemic lupus erythematosus with potentially fatal diffuse alveolar hemorrhage. Respiration 2015;89:62-5.

Copyright 2020 BMJ Publishing Group. All rights reserved. For permission to reuse any of this content visit

https://www.bmj.com/company/products-services/rights-and-licensing/permissions/

BMJ Case Report Fellows may re-use this article for personal use and teaching without any further permission.

Become a Fellow of BMJ Case Reports today and you can:

- Submit as many cases as you like

- Enjoy fast sympathetic peer review and rapid publication of accepted articles

- Access all the published articles

- Re-use any of the published material for personal use and teaching without further permission

\section{Customer Service}

If you have any further queries about your subscription, please contact our customer services team on +44 (0) 2071111105 or via email at support@bmj.com.

Visit casereports.bmj.com for more articles like this and to become a Fellow 